\title{
Microstructure stability: Optimisation of 263 Ni-based superalloy
}

\author{
Coraline Crozet ${ }^{\mathrm{a}}$, Alexandre Devaux, and Denis Béchet \\ Aubert\&Duval, Site des Ancizes, BP. 1, 63770 Les Ancizes Cedex, France
}

\begin{abstract}
To reduce $\mathrm{CO}_{2}$ emissions on coal-fired power plant, A-ultra supercritical (A-USC) power plant whose steam conditions exceed $700^{\circ} \mathrm{C}$ are being developed. At these elevated temperatures, the use of Ni-base superalloys becomes necessary. In this context and within the European project NextGenPower, focus is made on commercial Nimonic C-263 as a candidate material for turbine rotors. Nimonic C-263 is known to have low sensitivity to segregation, high workability and high weldability which are major properties for the manufacture of large shafts. Long-term creep strength is also required for this application and unfortunately Nimonic C-263 shows $\eta$-phase precipitation after long-time exposure between $700^{\circ} \mathrm{C}-900{ }^{\circ} \mathrm{C}$ which is detrimental for long-term creep properties. The composition of Nimonic C-263 was thus optimised to overcome the formation of $\eta$-phase. Trial tests were made in order to study the effect of hardening contribution elements on microstructural and mechanical properties. Then, a $500 \mathrm{~mm}$ diameter forged rotor was made from optimised 263 alloy and shows promising properties.
\end{abstract}

\section{Introduction}

To improve efficiency, future generation of steam power plants plan to operate at temperature higher than $700^{\circ} \mathrm{C}$. Nimonic C-263 is currently considered to be one of the best candidate materials before use in these high temperature applications [1].

Nimonic C-263 is a wrought Ni-based superalloy developed in 1960 by Rolls-Royce [2]. Nimonic C-263 is known to combine promising mechanical properties such as excellent elevated temperature strength, creep resistance, high corrosion and oxidation resistance [1], in addition to good process properties as the alloy shows low sensitivity to segregation, high workability and weldability. Its nominal composition is 19-21 Co, 19-21 Cr, 5.6-6.1 Mo, 1.9-2.4 Ti, $\leq 0.6 \mathrm{Al}, 0.04-0.08 \mathrm{C}$, and the balance Ni. (All compositions are in weight percent throughout this article, unless otherwise stated).

Solid solution strengthening and precipitation hardening are the two strengthening mechanisms, which occur in Nimonic 263. Precipitation hardening is the main strengthening mechanism in this alloy with the precipitation of gamma-prime $\left(\gamma^{\prime}\right)$ phase, which occurs during the precipitation hardening heat treatment. Solution strengthening elements such as molybdenum provide high temperature strengthening through lattice distortion due to its atomic size difference from the matrix [1]. Zhao et al. [3] reported that several phases precipitate on the austenite (fcc) matrix $(\gamma)$. MC carbides, rich in $\mathrm{Ti}$ and $\mathrm{Mo}$ in the form of (Ti, Mo) $\mathrm{C}$ are mainly intragranular. $\mathrm{M}_{23} \mathrm{C}_{6}$ carbides rich in $\mathrm{Cr}, \mathrm{Ni}$, Mo and $\mathrm{Co}$ precipitate at grain boundaries. The $\gamma^{\prime}-\mathrm{Ni}_{3}(\mathrm{Ti}, \mathrm{Al})$ phase, $\mathrm{L}_{2}$ crystal

a Corresponding author: coraline.crozet@erametaubertduval.com structure, and the $\eta-\mathrm{Ni}_{3} \mathrm{Ti}$ phase, hexagonal structure, precipitate at temperatures below $900{ }^{\circ} \mathrm{C}$. In long-time overaged samples, $\eta$ phase precipitates at the expense of $\gamma^{\prime}$ phase with a thin-plate morphology (Fig. 1). The time-temperature-transformation (TTT) diagram, given in Fig. 2, shows that for the temperatures of interest for the future power plants $\left(700^{\circ} \mathrm{C}-900^{\circ} \mathrm{C}\right), \eta$ phase will precipitate after 3000 hours at $750^{\circ} \mathrm{C}$ or 60 hours at $880^{\circ} \mathrm{C}$ and this precipitation will be detrimental for long-term creep strength [4].

In this context, Aubert\&Duval has focused its research on developing a new superalloy [5] based on Nimonic C-263 composition with higher microstructure stability at $750{ }^{\circ} \mathrm{C}$ while keeping process properties of Nimonic C-263.

\section{Alloy design - theoretical approach}

Three conditions were defined to optimise the Nimonic C-263 composition. The first condition was defined to improve microstructure stability at $750{ }^{\circ} \mathrm{C}$ and so to remove $\eta$ phase formation. Then, the second and third conditions concern process properties (workability, weldability, etc.) which were expected to be as good as those of Nimonic C-263. To satisfy these conditions $\gamma^{\prime}$ solvus and $\gamma^{\prime}$ content at $750^{\circ} \mathrm{C}$ have to be similar to those of Nimonic C-263. As we know, formation of $\eta$ and $\gamma^{\prime}$ phases are linked to $\mathrm{Ti}$ and $\mathrm{Al}$ contents. Consequently, Thermo-Calc ${ }^{\circledR}$ software with the database TCNI5 was used to define Ti-Al couples which satisfy the previous conditions.

The stability window of $\eta$ phase for Nimonic C-263 composition as a function of $\mathrm{Ti}$ and $\mathrm{Al}$ contents was determined and the boundary of the domain is plotted on

This is an Open Access article distributed under the terms of the Creative Commons Attribution License 4.0, which permits unrestricted use, distribution, and reproduction in any medium, provided the original work is properly cited. 


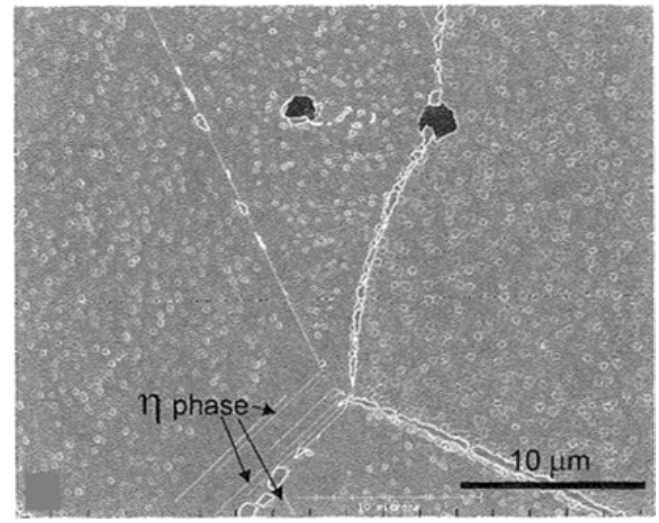

Figure 1. Example of thin plate morphology of $\eta$ phase in Nimonic 263 after annealing at $850^{\circ} \mathrm{C}$ for 1000 hours [3].

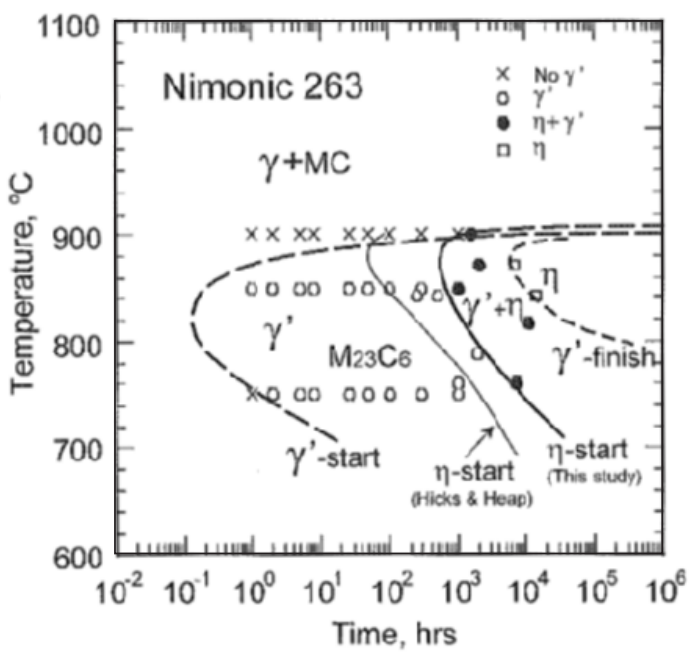

Figure 2. TTT diagram of Nimonic C-263 [3].

Fig. 3 (dash line). The Ti-Al couple for Nimonic C-263 is also reported on Fig. 3 and it appears that Nimonic C-263 lies in the stability window for $\eta$ phase. Nimonic C-263 $\gamma^{\prime}$ solvus calculated by Thermo-Calc ${ }^{\circledR}$ was found to be equal to $900^{\circ} \mathrm{C}$. Simulations were then made to determine all Ti-Al couples, which allow $900^{\circ} \mathrm{C}$ as $\gamma^{\prime}$ solvus and the results were plotted on Fig. 3 (solid line). Nimonic C-263 $\gamma^{\prime}$ content was calculated to be equal to $10 \mathrm{at} \%$ at $750{ }^{\circ} \mathrm{C}$. As for $\gamma^{\prime}$ solvus, Ti-Al couples which allow 10at $\%$ of $\gamma^{\prime}$ content at $750^{\circ} \mathrm{C}$ were determined and plotted on Fig. 3 (dash line). Simulations were also performed for 9 at $\%$ and $11 \mathrm{at} \% \gamma^{\prime}$ content at $750{ }^{\circ} \mathrm{C}$ in order to surround the $10 \mathrm{at} \%$ line.

The best compromise was then chosen for the optimised composition: composition in the area without $\eta$ formation, with a $\gamma^{\prime}$ solvus of $900^{\circ} \mathrm{C}$ and a $\gamma^{\prime}$ content at $750{ }^{\circ} \mathrm{C}$ of near $10 \%$ at. Ti-Al contents were then defined as $\% \mathrm{Al}$ of $0.83+/-0.05$ and $\% \mathrm{Ti}$ of $1.53+/-0.05$ (cross on Fig. 3).

\section{Experimental study}

\subsection{Trial tests $(150 \mathrm{~kg})$}

Materials for this study were melted and processed by Aubert\&Duval. Ingots of Nimonic C-263 and "Optimised"

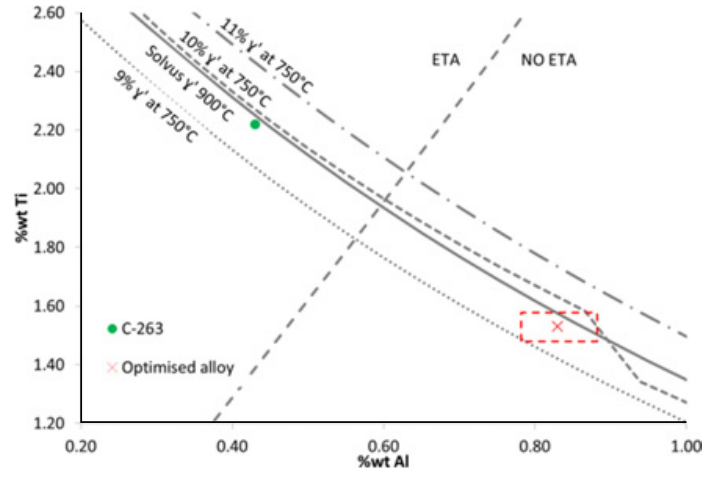

Figure 3. Thermo-Calc simulations to define stability window of $\eta$ phase, $\gamma^{\prime}$ solvus and $\gamma^{\prime}$ content at $750^{\circ} \mathrm{C}$.

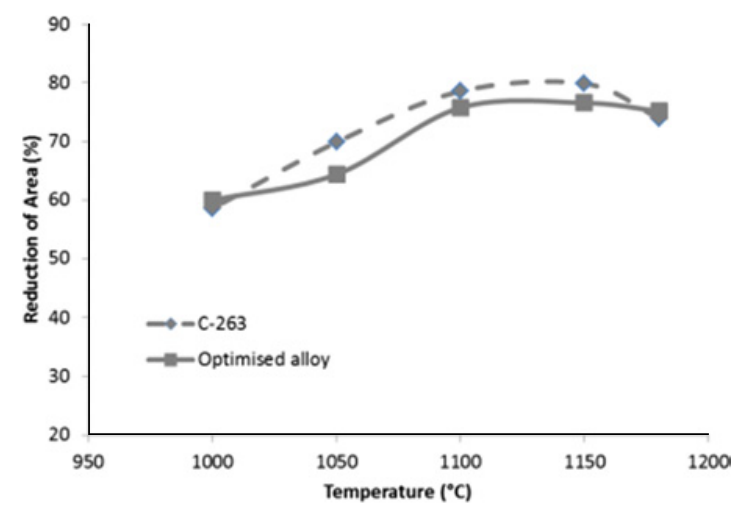

Figure 4. Workability curves for Nimonic C-263 and Optimised alloy.

Table 1. Experimental compositions of tested alloys (weight percent).

\begin{tabular}{|l|c|c|c|c|c|c|c|}
\hline & $\mathrm{Ni}$ & $\mathrm{Cr}$ & $\mathrm{Co}$ & $\mathrm{Mo}$ & $\mathrm{Ti}$ & $\mathrm{Al}$ & $\mathrm{C}$ \\
\hline C-263 & $\mathrm{Bal}$ & 19.7 & 20 & 5.8 & 2.2 & 0.42 & 0.05 \\
\hline Optimised alloy & $\mathrm{Bal}$ & 19.7 & 20 & 5.9 & 1.53 & 0.79 & 0.05 \\
\hline
\end{tabular}

alloy were produced through primary vacuum induction melting (VIM) and vacuum arc re-melting (VAR). Each of the VAR ingots was $200 \mathrm{~mm}$ in diameter and weighted about $150 \mathrm{~kg}$. Chemical analyses were performed and are given on Table 1. Most of the elemental compositions were well controlled although $\mathrm{Al}$ content in Optimised alloy is slightly lower than expected.

Before forging, workability tests were performed to determine the best range of forging temperatures and to compare both alloys. Samples were homogenised above $1150^{\circ} \mathrm{C}$ and then tensile tests were performed at high temperatures between $1000^{\circ} \mathrm{C}-1200^{\circ} \mathrm{C}$ and high speed $(1.9 \mathrm{~mm} / \mathrm{s})$ in order to simulate forging process. Results showed that Nimonic C-263 and Optimised alloy have similar workability (Fig. 4) and so should have the same behaviour during forging. The VAR ingots homogenised above $1150^{\circ} \mathrm{C}$ were forged successfully and the final billets of $80 \mathrm{~mm}$ diameter were obtained without surface cracks (Fig. 5).

Samples of $25 \mathrm{~mm}$ in length and $3.7 \mathrm{~mm}$ in diameter were prepared to perform dilatometry tests on a Netzsch (402C) device. Samples were heated until $1050{ }^{\circ} \mathrm{C}$ and then cooled until room temperature with a heating and 


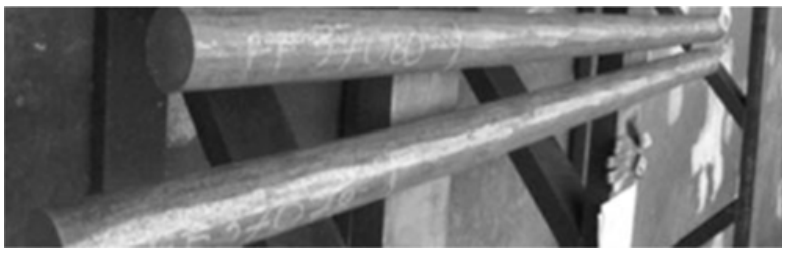

Figure 5. Photographs of the bars $80 \mathrm{~mm}$ diameter in Nimonic C-263 and Optimised alloy.

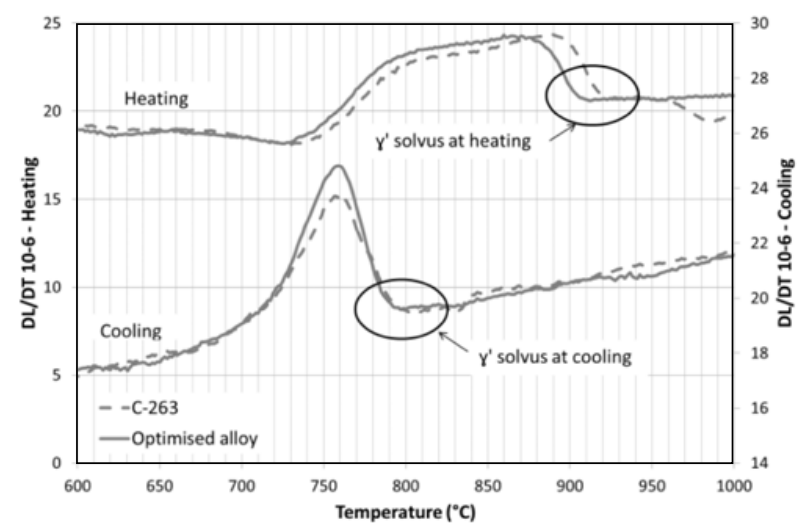

Figure 6. Dilatometry curves for Nimonic C-263 and Optimised alloy - Second cycle $\left(3^{\circ} \mathrm{C} / \mathrm{min}\right)$.

Table 2. Experimental and calculated $\gamma^{\prime}$ solvus temperatures.

\begin{tabular}{|l|l|l|l|}
\hline & Heating & Cooling & Calculated \\
\hline Nimonic C-263 & $925^{\circ} \mathrm{C}$ & $797^{\circ} \mathrm{C}$ & $892^{\circ} \mathrm{C}$ \\
\hline Optimised alloy & $912^{\circ} \mathrm{C}$ & $795^{\circ} \mathrm{C}$ & $886^{\circ} \mathrm{C}$ \\
\hline
\end{tabular}

cooling rate of $3{ }^{\circ} \mathrm{C} / \mathrm{min}$. For each sample, two successive cycles were made. Derivative curves for heating and cooling obtained on the second cycle are given on Fig. 6 . The first observation is that curves show that $\gamma^{\prime}$ solvus temperatures are close for both alloys although Optimised alloy seemed to have a slightly lower $\gamma^{\prime}$ solvus temperature than that of Nimonic C-263 on heating.

$\gamma^{\prime}$ solvus temperatures obtained experimentally are summarised on Table 2 and compared with calculated $\gamma^{\prime}$ solvus temperatures. Due to the slow heating rate for dilatometry tests, experimental results are in good agreement with calculated $\gamma^{\prime}$ solvus temperatures. Optimised alloy has a lower $\gamma^{\prime}$ solvus temperature than expected, which could be due to lower $\mathrm{Al}$ content obtained on the trial ingot. To design Optimised alloy, hypothesis were made that $\gamma^{\prime}$ solvus temperature and $\gamma^{\prime}$ content at $750{ }^{\circ} \mathrm{C}$ have to be similar to those of Nimonic C-263. First results on workability and dilatometry tests performed on trial ingots showed that both conditions were validated for the chosen composition of Optimised alloy.

Sections were cut from the bars in order to produce a series of samples for metallurgical analysis. All samples have undergone a solution heat treatment of $1150{ }^{\circ} \mathrm{C}$ for 2 hours before being air cooled to room temperature. All samples were then aged at $800^{\circ} \mathrm{C}$ for 8 hours and finally air cooled to room temperature. As shown on Fig. 7, similar grain sizes (2 ASTM average grain size) were obtained on experimental alloys. Both alloys are $\gamma^{\prime}$ strengthened with only one population of secondary $\gamma^{\prime}$ precipitates with
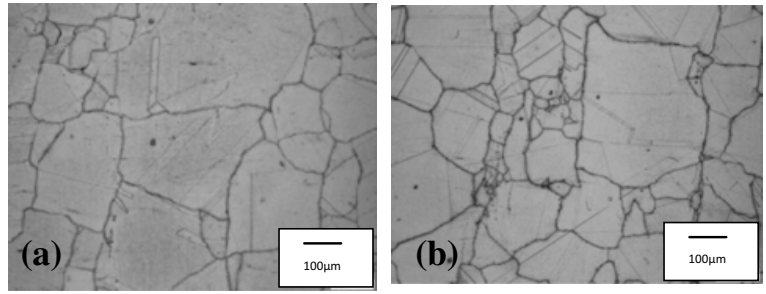

Figure 7. Optical micrographs of experimental alloys. (a) Nimonic C-263; (b) Optimised alloy.

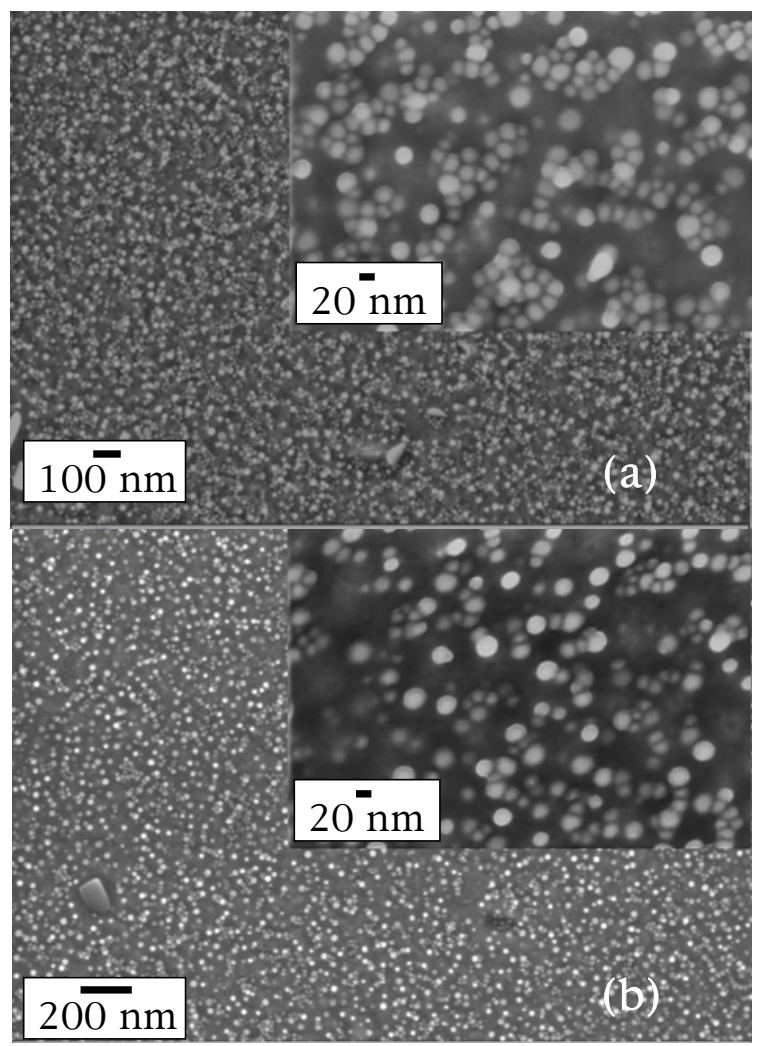

Figure 8. FEG-SEM micrographs of experimental alloys. (a) Nimonic C-263; (b) Optimised alloy.

the same size (around $22 \mathrm{~nm}$ ) observed from a scanning electron microscope (FEG-SEM) (Fig. 8).

\subsection{Industrial test (6 tons)}

Industrial ingot of Optimised alloy was produced through primary vacuum induction melting (VIM) and vacuum arc re-melting (VAR). VAR ingot was $640 \mathrm{~mm}$ in diameter and weighted about 6 tons. Chemical analysis was performed and is given in Table 3. As for trial ingot, the Al content is slightly lower than expected. The VAR ingot homogenised above $1150^{\circ} \mathrm{C}$ was forged successfully and the final billet of $500 \mathrm{~mm}$ diameter was obtained without surface cracks (Fig. 9). Ultrasonic Testing control and macrographic observations were performed and no defects were detected. Workability and low segregation sensitivity as good as Nimonic C-263 were so proved for Optimised alloy with this industrial test.

Disks of $200 \mathrm{~mm}$ length were cut from the industrial bar and then heat treated at $1130{ }^{\circ} \mathrm{C} / 2 \mathrm{~h} /$ water quenched + 
Table 3. Experimental composition of industrial Optimised alloy.

\begin{tabular}{|l|l|l|l|l|l|l|l|}
\hline Wt\% & $\mathrm{Ni}$ & $\mathrm{Cr}$ & $\mathrm{Co}$ & $\mathrm{Mo}$ & $\mathrm{Ti}$ & $\mathrm{Al}$ & $\mathrm{C}$ \\
\hline Optimized alloy & $\mathrm{Bal}$ & 19.8 & 20 & 6.1 & 1.51 & 0.78 & 0.05 \\
\hline
\end{tabular}

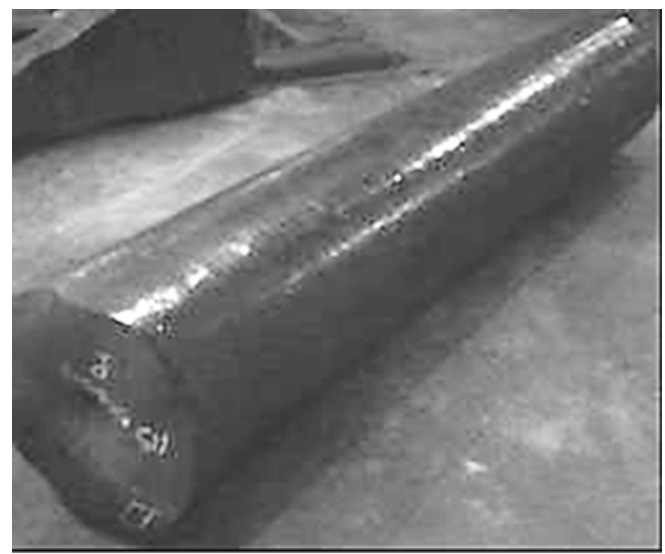

Figure 9. Photograph of Optimised alloy bar of $500 \mathrm{~mm}$ diameter without cracks.

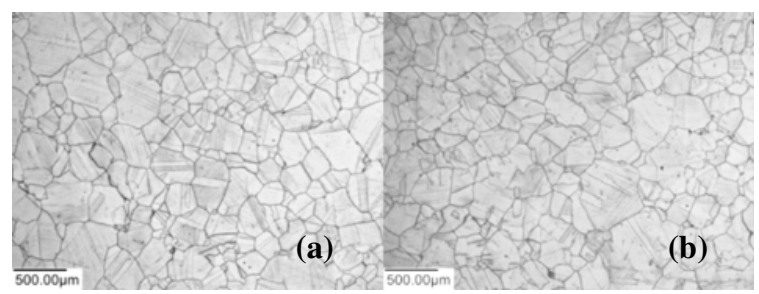

Figure 10. Optical micrographs of industrial disks in Optimised alloy (200 mm length and $500 \mathrm{~mm}$ diameter) - (a) core - (b) rim.

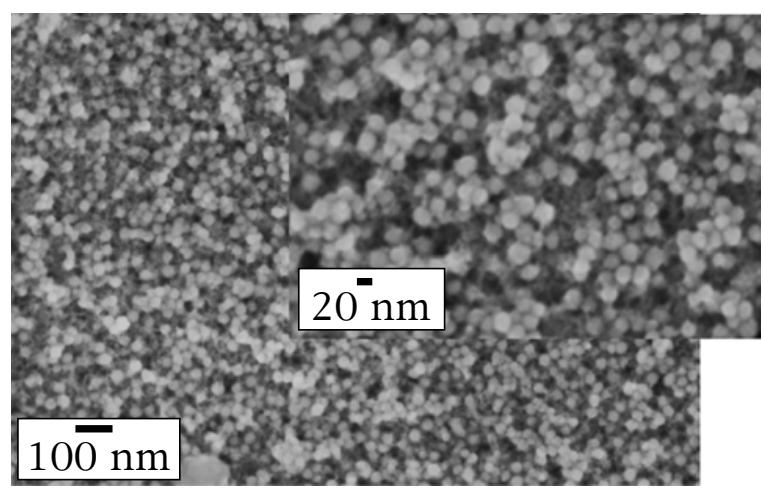

Figure 11. FEG-SEM micrographs of industrial disks in Optimised alloy.

$800^{\circ} \mathrm{C} / 8 \mathrm{~h} /$ Air cooled. A homogeneous grain size (around 2 ASTM) was obtained in both the core and rim of the disks (Fig. 10). Only one population of secondary $\gamma^{\prime}$ precipitates was also observed on industrial disks with the same size as those in trial tests (around $23 \mathrm{~nm}$ ) (Fig. 11).

\section{Alloys properties and discussion}

\subsection{Standard heat treatment}

Mechanical tests were performed on both trial alloys (Nimonic C-263 and Optimised alloy) after standard heat treatment $\left(1150^{\circ} \mathrm{C} / 2 \mathrm{~h} /\right.$ Air $+800^{\circ} \mathrm{C} / 8 \mathrm{~h} /$ Air $)$.

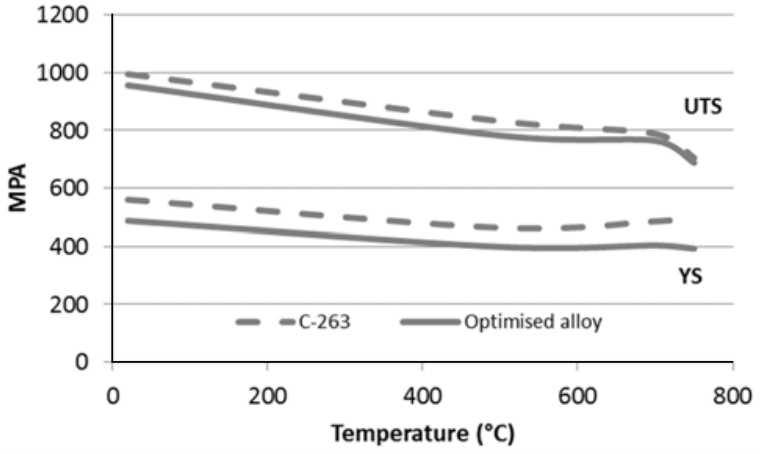

Figure 12. Tensile strength for Nimonic C-263 and Optimised alloy after standard heat treatment.

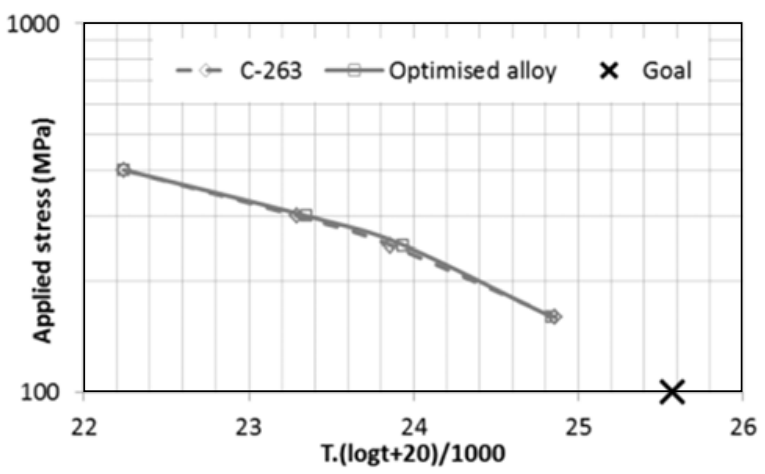

Figure 13. Creep results on Nimonic C-263 and Optimised alloy after standard heat treatment.

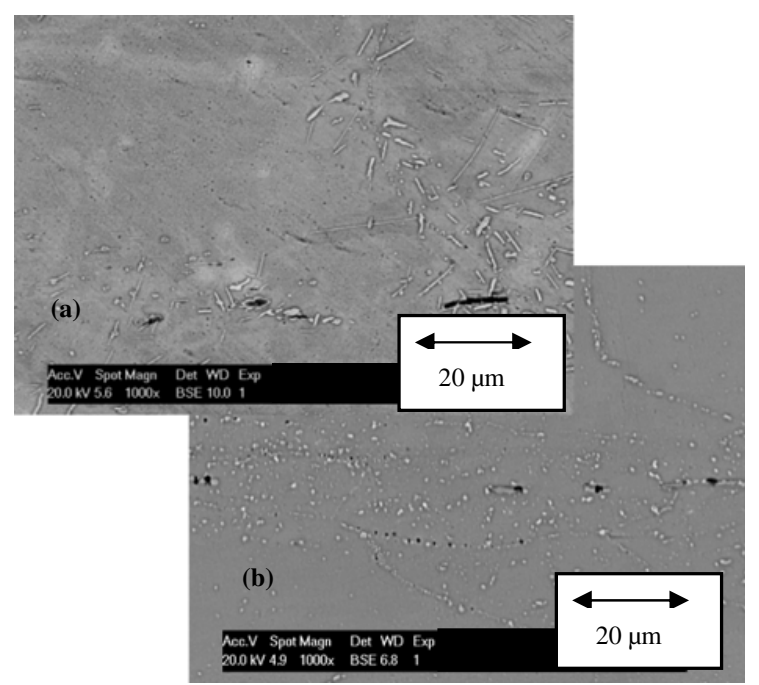

Figure 14. SEM micrographs of tensile samples aged at $870^{\circ} \mathrm{C}$ for $100 \mathrm{~h}$. (a) Nimonic C-263 with white plates of $\eta$ phase (b) Optimised alloy without $\eta$ phase.

Tensile tests were performed at room temperature, $500^{\circ} \mathrm{C}, 700^{\circ} \mathrm{C}$ and $750^{\circ} \mathrm{C}$ and creep tests were performed at $750^{\circ} \mathrm{C}$ for applied stresses of 400,300 and $250 \mathrm{MPa}$ and $810^{\circ} \mathrm{C}$ for $250 \mathrm{MPa}$. Figures 12 and 13 summarise the results and show that similar properties are obtained for both alloys. It can be noted however, that tensile properties for Optimised alloy are slightly lower than those of Nimonic C-263. This result could be explained by the 


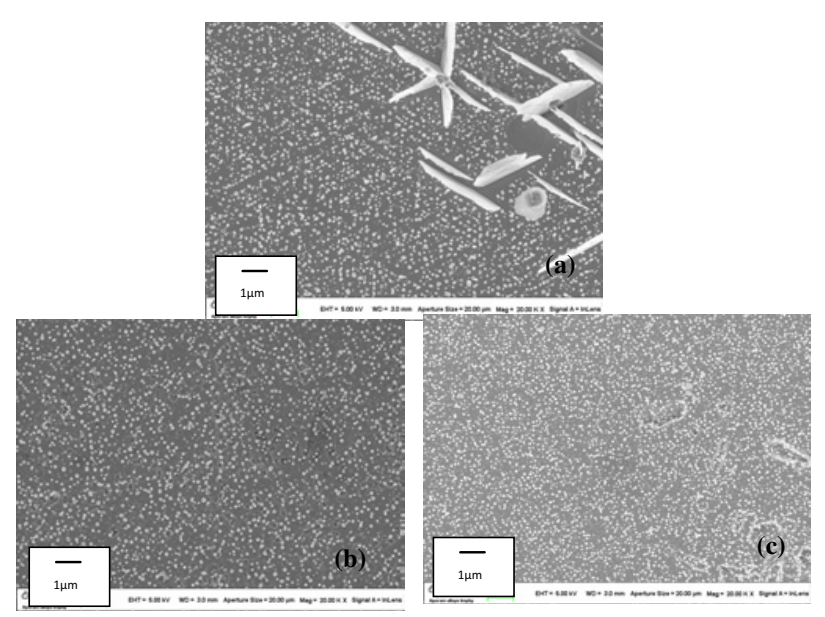

Figure 15. SEM micrographs of samples aged at $750{ }^{\circ} \mathrm{C}$ for 3000 hours. (a) Nimonic C-263; (b) Optimised alloy (trial test); (c) Optimised alloy (industrial test).

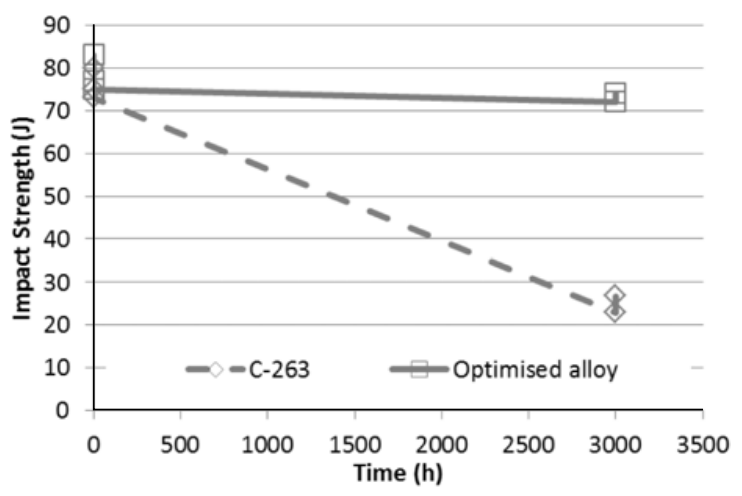

Figure 16. Impact strengths on Nimonic C-263 and Optimised alloy without over-ageing and with over-ageing at $750^{\circ} \mathrm{C}$ for 3000 hours.

low Al content on Optimised alloy and so a lower $\gamma^{\prime}$ fraction than expected.

\subsection{Long-term ageing}

To check the absence of $\eta$ phase precipitates in the Optimised alloy, room temperature tensile samples were aged at $870^{\circ} \mathrm{C}$ for 100 hours. Nimonic C-263 TTT curve (Fig. 2) shows that for these conditions, $\eta$ phase should precipitate in Nimonic C-263. Microstructural observations were then made on the broken zone of each room tensile sample (Fig. 14). Precipitation of white plates identified as $\eta$ phase was only observed in Nimonic C-263 and not in Optimised alloy. Consequently, for the same experimental conditions we showed that Optimised alloy has better microstructure stability and is less prone to $\eta$ phase precipitation than Nimonic C-263.

In order to confirm these first results of $\eta$ phase precipitation and to test the impact of $\eta$ phase precipitation on mechanical properties, samples from trial and industrial tests were aged at $750{ }^{\circ} \mathrm{C}$ for 3000 hours. White plates of $\eta$ phase are observed on Nimonic C-263 whereas no $\eta$ phase precipitation appeared on Optimised alloy (Fig. 15). The first condition for the design of the

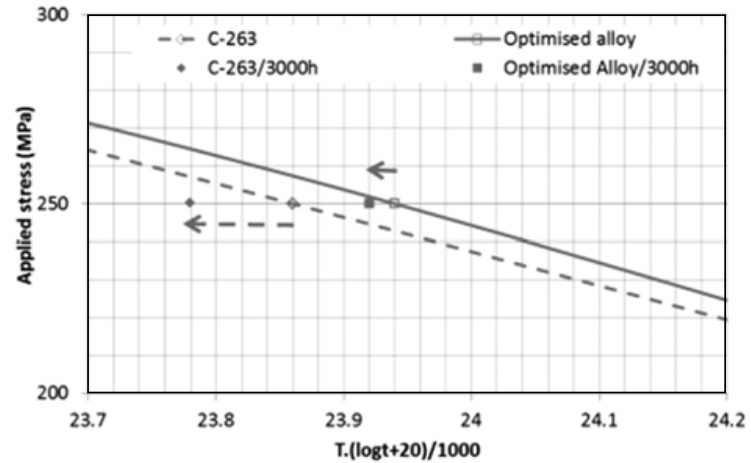

Figure 17. Creep results on Nimonic C-263 and Optimised alloy without over-ageing and with over-ageing at $750{ }^{\circ} \mathrm{C}$ for 3000 hours.

Optimised alloy is so satisfied with higher microstructure stability at $750{ }^{\circ} \mathrm{C}$ regarding $\eta$ phase precipitation.

Charpy impact tests at room temperature and creep tests at $750{ }^{\circ} \mathrm{C} / 250 \mathrm{MPa}$ were performed on samples aged at $750{ }^{\circ} \mathrm{C}$ for 3000 hours. Results were compared with results obtained on as-heat treated samples. For Optimised alloy, long-term ageing at $750^{\circ} \mathrm{C}$ has no effect on impact strength whereas it is significantly reduced for Nimonic C-263 (Fig. 16). Figure 17 shows a greater influence of long-term ageing on creep rupture life of Nimonic C-263 than for Optimised alloy. It strongly suggests that the precipitation of $\eta$ phase in C-263 is responsible for the decrease in mechanical properties.

\section{Conclusions}

Aubert\&Duval has optimised Nimonic C-263 grade based on three criteria: higher microstructure stability regarding $\eta$ phase precipitation and similar $\gamma^{\prime}$ solvus temperature and $\gamma^{\prime}$ content at $750{ }^{\circ} \mathrm{C}$ as Nimonic C-263 to preserve similar workability and properties of C-263. We demonstrated on a trial test and an industrial test that the Optimised alloy has actually better microstructure stability than Nimonic C-263 with no $\eta$ phase precipitation and has process properties (workability and segregation tendency) as good as Nimonic C-263. Regarding mechanical properties after standard heat treatment, they are similar as Nimonic C263 mechanical properties even if tensile properties could be improved on Optimized alloy with better arrangement of $\mathrm{Ti}$ and $\mathrm{Al}$ contents. Finally, we showed that $\eta$ phase precipitation after ageing at $750{ }^{\circ} \mathrm{C}$ for 3000 hours has detrimental effects on impact strength and creep rupture life. This new superalloy is thus promising with a high potential for applications at high temperature and long time as on future A-USC steam turbine.

Authors wish to thank the Aperam Research Center of for FEGSEM observations. The authors would also like to acknowledge the financial support of NextGenPower project (Project No. ENER/FP7EN/249745/“NextGenPower")-Meeting the Materials and Manufacturing Challenge for Ultra High Efficiency PF Power Plants with CCS, and all the partners involved. 


\section{References}

[1] S.A. Smith, G.D West, K. Chi, W. Gamble, R.C Thomson, Adv. in Materials Technology for Fossil Power Plants, Proc. from the Sixth Iint. Conf., 110126 (2010)

[2] Special Metals: Nimonic alloy 263. SMC-054 (2004)
[3] J.C. Zhao, V. Ravikumar, A.M. Beltran, Met. Trans. A, 32 (6), 1271-1282 (2001)

[4] C.T. Sims, N.S. Stoloff, W.C. Hagel, Superalloys II High-Temperature Materials for Aerospace and Industrial Power. 110-111 (1987)

[5] Patent application is pending 